1 University of Warwick, UK

2 University of Bath, UK

Adam.briggs@warwick.ac.uk

Follow Adam Briggs on Twitter @ADMBriggs

Follow Harry Rutter on Twitter @harryrutter

Cite this as: $B M J$ 2020:369:m1977 http://dx.doi.org/10.1136/bmj.m1977 Published: 18 May 2020

\section{Public health policies can reduce inequalities as we come out of lockdown}

\section{Population level public health policies have an important part in supporting the transition out of lockdown}

\author{
Adam Briggs, ${ }^{1}$ Harry Rutter ${ }^{2}$
}

As the UK moves beyond the first wave peak, the national conversation surrounding covid-19 has shifted to how to lift the lockdown safely-when restrictions should be relaxed, who can go back to school or work first, which limits should stay in place, and how this can be done in a way that's safe, transparent, data led, and adaptable as new evidence emerges.

Straightforward population level public health policies have an important part in supporting this transition, reducing the impact of covid-19 on inequalities and ensuring that the health and care system can provide for people when they need it.

We weren't alone in writing about this topic earlier in the pandemic, but progress has been disappointing. ${ }^{12}$ We argued for lower speed limits after reports of terrifying driving, ${ }^{3}$ we suggested raising the legal age for buying tobacco and providing free nicotine replacement, and we proposed limiting the amount of alcohol that can be bought per transaction, alongside accelerating the introduction of minimum unit pricing in England.

Such policies weren't chosen at random. As we wrote at the time, they were selected based on evidence that they "could free up NHS capacity and save lives in the short term, as well as improve population health and wellbeing in the medium to long term." It feels as though much of the world has moved on with these discussions, but the UK has largely lagged behind.

France, Germany, and Italy have all made significant moves to ensure people can use active travel to get to work safely by initiatives ranging from temporary cycle lanes to free bike repairs. ${ }^{-6}$ And on 9 May the government, somewhat belatedly, followed suit when Transport Secretary Grant Shapps announced the first €25om (€282m; \$305m) of a €2bn investment in cycling and walking infrastructure in England. ${ }^{7}$ The announcement included the welcome publication of new local authority statutory guidance on reallocating road space-compelling local governments to repurpose roads away from cars and towards bikes and pedestrians-and recommending lower speed limits in built up areas. ${ }^{8}$ Such investment and guidance are crucial to ensuring that people don't crowd public transport or resort to private vehicles when returning to work. But when you consider that Greater Manchester's 1800 mile cycling and walking network alone is estimated at $€ 1.5 \mathrm{bn}$, the promised £2bn is unlikely to fund the necessary long term shift towards active travel. ${ }^{9}$
Recent reports suggest that as many as 300000 smokers may have quit during the lockdown, with four times as many actively trying to follow suit. ${ }^{10}$ Covid-19 has helped to shift people from contemplation to preparation, and from preparation to action-with potentially important implications for inequalities. ${ }^{11}$ Smoking rates among unemployed adults are $29 \%$ compared with $15 \%$ among those with jobs, and people in routine or manual work are over twice as likely to smoke as managers or professionals. ${ }^{12}$ One wonders how many additional smokers would have stopped if more support had been made available.

Drinking habits have also changed. A survey from the charity Alcohol Change UK suggests that up to a third of UK adults have reduced how much they drink compared with a fifth that have increased consumption. ${ }^{13}$ While welcome, closer reading of the data tells us that those who drink most often are the least likely to have cut back-those dependent drinkers who are most likely to respond to policies such as minimum unit pricing. ${ }^{14}$ And alcohol doesn't just harm the physical and mental health of the individual, it impacts the entire home including the risk and severity of domestic abuse. ${ }^{15}$

In addition to the inequalities in covid-19 outcomes by ethnicity, there is growing evidence that it is having a much greater impact on those least able to cope-people who are more deprived and have lower incomes. ${ }^{16}$ Mortality data show that most deprived populations have over double the covid-19 death rate of the least deprived. ${ }^{17}$ Economic data suggest that those working in the most insecure and lowest paid jobs are least likely to have been able to work from home, are more affected by loss of employment, and are more vulnerable to housing insecurity. ${ }^{18}$ The growth of informal community networks is weighted towards the most socioeconomically advantaged parts of the country. ${ }^{19}$ And the forthcoming global economic recession may mean further cuts to national and local government services that protect the most vulnerable. ${ }^{20}$

The repercussions of covid-19 will be felt for years to come. It can't be used as an excuse for worsening population health and widening inequalities, but instead needs to be an opportunity for a healthier and more equal society. Public health policies taken now can reduce short term NHS demand, improve population health, and limit the impact on inequalities. Beyond these immediate measures we need a long term government inequalities strategy 
to support those most acutely affected by covid-19, both now and in the future. ${ }^{21}$

Competing interests: AB's research at the University of Warwick is supported by the National Institute for Health Research Applied Research Collaboration West Midlands.

Not commissioned, not peer reviewed.

1 Bhopal S, Bola GK, Hughes R, Gopfert A, Bhopal A. Can we improve the NHS's ability to tackle covid-19 through emergency public health interventions? 24 March 2020.

https://blogs.bmj.com/bmj/2020/03/24/can-we-improve-the-nhss-ability-to-tackle-covid-19through-emergency-public-health-interventions.

2 Let's use lockdown to break old habits and start afresh with healthier new ones. Telegraph. www.telegraph.co.uk/global-health/climate-and-people/use-lockdown-break-old-habits-startafresh-healthier-new-ones.

3 Police urge drivers to slow down as extreme speeding enforcement soars. Metropolitan Police. 7 May 2020. http://news.met.police.uk/news/police-urge-drivers-to-slow-down-as-extremespeeding-enforcement-soars-401835.

4 UK urged to follow Europe's lead in expanding bike lanes to help with social distancing. Telegraph. 23 April 2020. www.telegraph.co.uk/news/2020/04/23/uk-urged-follow-europes-lead-expandingbike-lanes-help-social.

5 Pop-up bike lanes help with coronavirus physical distancing in Germany. Guardian. 13 April 2020. www.theguardian.com/world/2020/apr/13/pop-up-bike-lanes-help-with-coronavirus-social-distancing-in-germany.

$6 \quad$ Whiting K. France's plan to push pedal power to keep post-pandemic pollution levels low. World Economic Forum. May 2020. www.weforum.org/agenda/2020/05/france-air-pollution-cyclingpublic-transport-bike-coronavirus.

7 Department for Transport, Office for Low Emission Vehicles, Shapps G. $£ 2$ billion package to create new era for cycling and walking. www.gov.uk/government/news/2-billion-package-tocreate-new-era-for-cycling-and-walking.

8 Reallocating road space in response to covid-19: statutory guidance for local authorities. www.gov.uk/government/publications/reallocating-road-space-in-response-to-covid-19-statutoryguidance-for-local-authorities

9 Greater Manchester cycling and walking network revolutionary, report claims. ITV News. 28 January 2020. www.itv.com/news/granada/2020-01-28/greater-manchester-cycling-and-walkingnetwork-revolutionary-report-claims.

10 More than 300000 UK smokers may have quit owing to covid-19 fears. Guardian. 4 May 2020 www.theguardian.com/society/2020/may/04/more-than-300000-uk-smokers-may-have-quitowing-to-covid-19-fears.

11 Prochaska JO, Velicer WF. The transtheoretical model of health behavior change. Am J Health Promot 1997;12:38-48. doi: 10.4278/0890-1171-12.1.38 pmid: 10170434

12 NHS Digital. Statistic on smoking in England, 2019. https://digital.nhs.uk/data-and-information/publications/statistical/statistics-on-smoking/statistics-on-smoking-england-2019/part-3-smokingpatterns-in-adults-copy.

13 Alcohol Change UK. Drinking during lockdown. 2020. https://alcoholchange.org.uk/blog/2020/covid19-drinking-during-lockdown-headline-findings.

14 O’Donnell A, Anderson P, Jané-Llopis E, Manthey J, Kaner E, Rehm J. Immediate impact of minimum unit pricing on alcohol purchases in Scotland: controlled interrupted time series analysis for 2015-18. BMJ 2019;366:15274. doi: 10.1136/bmj.l5274 pmid: 31554617

15 World Health Organization. Intimate partner violence and alcohol fact sheet. www.who.int/violence_injury_prevention/violence/world_report/factsheets/ft_intimate.pdf.

16 Office for National Statistics. Coronavirus (covid-19) related deaths by ethnic group, England and Wales: 2 March 2020 to 10 April 2020. www.ons.gov.uk/peoplepopulationandcommunity/birthsdeathsandmarriages/deaths/articles/coronavirusrelateddeathsbyethnicgroupenglandandwales/2march2020to10april2020.

17 Office for National Statistics Coronavirus. (covid-19) related deaths by ethnic group, England and Wales. 1 May 2020. www.ons.gov.uk/peoplepopulationandcommunity/birthsdeathsandmarriages/deaths/bulletins/deathsinvolvingcovid19bylocalareasanddeprivation/deathsoccurringbetween1marchand17april.

18 Economic impacts of the coronavirus crisis on different groups of workers. Resolution Foundation. www.resolutionfoundation.org/publications/risky-business

19 Felici M. Social capital and the response to covid-19. Bennett Institute for Public Policy. www.bennettinstitute.cam.ac.uk/blog/social-capital-and-response-covid-19.

20 Urgent call for $f 1 \mathrm{bn}$ a year to reverse cuts to public health funding. Health Foundation. 12 June 2019. www.health.org.uk/news-and-comment/news/urgent-call-for-1-billion-a-year-to-reversecuts-to-public-health-grant.

21 Will covid-19 be a watershed moment for health inequalities? Health Foundation. 7 May 2020. www.health.org.uk/publications/long-reads/will-covid-19-be-a-watershed-moment-for-healthinequalities.

This article is made freely available for use in accordance with BMJ's website terms and conditions for the duration of the covid-19 pandemic or until otherwise determined by BMJ. You may use, download and print the article for any lawful, non-commercial purpose (including text and data mining) provided that all copyright notices and trade marks are retained. 